\title{
GMR
}

\section{Genetic diversity and population structure of Fenneropenaeus penicillatus determined by mitochondrial DNA analyses}

\author{
Y.Y. Cao ${ }^{1,2}$ and Z.B. $\mathrm{Li}^{1,2}$ \\ ${ }^{1}$ Fisheries College, Jimei University, Xiamen, China \\ ${ }^{2}$ Fujian Provincial Key Laboratory of Marine Fishery \\ Resources and Eco-Environment, Xiamen, China \\ Corresponding author: Z.B. Li \\ E-mail: lizhongbao@jmu.edu.cn \\ Genet. Mol. Res. 15 (3): gmr.15038503 \\ Received January 27, 2016 \\ Accepted April 8, 2016 \\ Published August 29, 2016 \\ DOI http://dx.doi.org/10.4238/gmr.15038503
}

Copyright $(C 2016$ The Authors. This is an open-access article distributed under the terms of the Creative Commons Attribution ShareAlike (CC BY-SA) 4.0 License

\begin{abstract}
Fenneropenaeus penicillatus is a widely distributed economically and ecologically important shrimp species, which is endangered in China. Sequence analysis of 16s rRNA and control region (CR) fragments from mitochondrial DNA was conducted to obtain information on genetic diversity and population structure. Individuals from 12 wild $F$. penicillatus populations located along the southeast coast of China were used. Polymerase chain reaction (PCR) fragments of the $\mathrm{CR}$ gene revealed high genetic diversity among the 12 populations; however, PCR fragments of the 16s rRNA gene revealed very low genetic diversity in the Hainan $(\mathrm{HN})$ and Ningde (ND) populations and high genetic diversity in the DS, BH, PT, XM, and SZ populations. Data obtained from the CR and 16s rRNA genes suggested that high genetic differentiation exists among the 12 populations, which
\end{abstract}


is mainly due to the high genetic differentiation between $\mathrm{HN}$ and all other 11 populations. These results may be useful for further sustainable management and utilization of this species.

Key words: Fenneropenaeus penicillatus; mtDNA; 16s rRNA; Control region; Genetic diversity; Population structure

\section{INTRODUCTION}

Fenneropenaeus penicillatus (Alcock, 1905, common name: red tail prawn or red tail shrimp) plays important roles in estuarine and marine ecosystems. It has a high commercial value for both harvest and aquaculture, especially in Asia. However, the rapid decrease of wild stocks mainly due to overexploitation, as well as a decrease in aquaculture because of shrimp disease, has drew attention to the conservation and sustainable management of the species. In addition, in 2005, F. penicillatus was listed in the Red List of China Endangered Species. However, few genetic studies have been conducted on this species (Cao et al., 2012; Zhang et al., 2012; Shangguan et al., 2014; Yuan et al., 2015).

Analyses of genetic diversity and population structure provide baseline information for maintaining productive fisheries, sustainable harvesting (Park and Moran, 1994; Thorrold et al., 2002), and conservation (McNeely et al., 1990). Furthermore, assessments of genetic variation and structure can be useful for the evaluation of ongoing evolutionary processes and historical factors (Sloan et al., 2008). While methods to study the taxonomy, biology, biochemistry, and aquaculture are well developed for F. penicillatus (Chen et al., 1997; Chai, 2001; Kamal et al., 2015), more genetic information is needed for the species.

Mitochondria are the major energy producers in eukaryotic cells and have coexisted and coevolved over millions of years with eukaryotic nuclear DNA (Blier et al., 2001; Dyall et al., 2004). Molecular markers, including protein, nuclear, and mitochondrial DNA (mtDNA) markers, are employed to assess genetic diversity and population structure in freshwater and marine species (Englbrecht et al., 2000; Whitehead et al., 2003). mtDNA is of great interest to population geneticists for the study of phylogeographic structure and historical demography due to its unique features, including maternal inheritance, absence of recombination, and faster mutation rate compared to nuclear genome markers (Francalacci et al., 1996). The use of mtDNA is a classic and cost-efficient way to study populations and biodiversity. Because evolutionary rates are highly variable within the mitochondrial genome, the use of multiple genetic markers will enhance the power of genetic studies, in contrast to the use of a single genetic marker (Gruenthal et al., 2007).

In this study, we analyzed the sequences of control region (CR) and of 16s rRNA genes in mtDNA from F. penicillatus in order to obtain a more complete picture of the genetic diversity and population structure of this species. CR is located in the noncoding region of the mitochondrial genome and evolves at a higher rate than cytochrome $\mathrm{b}$ and cytochrome oxidase I (COI), which possess the highest evolutionary rates within the coding region. Thus, $\mathrm{CR}$ is utilized in evolutionary analyses due to its high variability in hypervariable segments. 16s rRNA genes are much less diverse; however, an important aspect of rRNA genes is their secondary structures, which are moderately well conserved among distantly related taxa (Caetano-Anollés, 2002). The 16s rRNA gene has been widely used to explore the phylogenetic

Genetics and Molecular Research 15 (3): gmr.15038503 
relationships in marine species at varying taxonomic levels ( $\mathrm{Li}$ et al., 2008). Therefore, $\mathrm{CR}$ and 16S rRNA genes have great potential for the inference of genetic diversity and population structure in F. penicillatus.

Francisco and Galetti (2005) used mtDNA 16s rRNA and COI regions to evaluate the genetic relationship between five brood stocks of the white marine shrimp Litopenaeus vannamei. Quan et al. (2004) also used COI and 16s rRNA genes to examine the phylogenetic relationships between 12 Penaeid shrimp species. Many other genetic studies have used mtDNA to identify the genetic diversity and population structure in shrimp species (Duda and Palumbi, 1999; McMillen-Jackson and Bert, 2004; Croos and Pálsson, 2010); however, no studies on mtDNA variation in F. penicillatus have been reported. The present study aimed to analyze the genetic diversity and population structure of 12 wild $F$. penicillatus populations along the southeast coast of China using mtDNA CR and 16s rRNA segments. The results will provide baseline genetic information on the species, which is essential for its future conservation and sustainable management.

\section{MATERIAL AND METHODS}

\section{Sample collection}

Wild samples from 12 F. penicillatus populations distributed along the Southeast coast of China were collected between 2006 and 2011 when fresh and mature. Samples were kept on ice and then transferred to a $-20^{\circ} \mathrm{C}$ freezer until use. Around 6-9 samples from each population were analyzed (except for two individuals from the Shenzheng population for the CR gene). The location and time of collection are shown in Table 1 and Figure 1.

Table 1. Sampling sites and sampling dates for Fenneropenaeus penicillatus populations in this study.

\begin{tabular}{l|l|l|c}
\hline Population & Abbreviation & Latitude/longitude & Date \\
\hline Ningde & ND & $26^{\circ} 38^{\prime} 15^{\prime \prime} \mathrm{N}, 119^{\circ} 35^{\prime} 49^{\prime \prime} \mathrm{E}$ & $2007-10-20$ \\
\hline Lianjiang & LJ & $26^{\circ} 10^{\prime} 39^{\prime \prime} \mathrm{N}, 119^{\circ} 37^{\prime} 18^{\prime \prime} \mathrm{E}$ & $2007-09-08$ \\
\hline Putian & PT & $25^{\circ} 24^{\prime} 30^{\prime \prime} \mathrm{N}, 119^{\circ} 06^{\prime} 49^{\prime \prime} \mathrm{E}$ & $2006-11-20$ \\
\hline Quanzhou & QZ & $24^{\circ} 50^{\prime} 47^{\prime \prime} \mathrm{N}, 118^{\circ} 37^{\prime} 09^{\prime \prime} \mathrm{E}$ & $2007-11-15$ \\
\hline Xiamen & XM & $24^{\circ} 24^{\prime} 07^{\prime \prime} \mathrm{N}, 118^{\circ} 08^{\prime} 49^{\prime \prime} \mathrm{E}$ & $2007-10-29$ \\
\hline Zhangpu & ZP & $2007-09-28$ \\
\hline Dongshan & DS & $24^{\circ} 00^{\prime} 22^{\prime \prime} \mathrm{N}, 117^{\circ} 43^{\prime} 06^{\prime \prime} \mathrm{E}$ & $2007-05-06$ \\
\hline Nanao & $23^{\circ} 44^{\prime} 06^{\prime \prime} \mathrm{N}, 117^{\circ} 16^{\prime} 44^{\prime \prime} \mathrm{E}$ & $2007-05-25$ \\
\hline Shenzheng & NA & $23^{\circ} 24^{\prime} 00^{\prime \prime} \mathrm{N}, 117^{\circ} 01^{\prime} 34^{\prime \prime} \mathrm{E}$ & $2007-09-08$ \\
\hline Hainan & SZ & $22^{\circ} 27^{\prime} 05^{\prime \prime} \mathrm{N}, 114^{\circ} 13^{\prime} 49^{\prime \prime} \mathrm{E}$ & $2011-12-13$ \\
Zhanjiang & HN & $18^{\circ} 59^{\prime} 03^{\prime \prime} \mathrm{N}, 110^{\circ} 50^{\prime} 27^{\prime \prime} \mathrm{E}$ & $2011-10-12$ \\
Beihai & ZJ & $21^{\circ} 05^{\prime} 50^{\prime \prime} \mathrm{N}, 110^{\circ} 44^{\prime} 31^{\prime \prime} \mathrm{E}$ & $2011-10-15$ \\
\hline
\end{tabular}

\section{DNA extraction and sequencing}

Genomic DNA was extracted using gene DNA extraction kit SK 1252 (Sangon Biotech., Shanghai Co., Ltd., Shanghai) according to the manufacturer instructions. DNA yield was estimated followed by electrophoresis on $1 \%$ agarose gel and ultraviolet spectrophotometry.

The optimal amplification conditions were as follows: 10X Taq polymerase buffer with $\mathrm{MgCl}_{2}, 1.25 \mathrm{U}$ Taq DNA polymerase (Promega Inc., USA), $100 \mathrm{ng}$ template DNA, 12.5 $\mu \mathrm{mol}$ forward primer, $12.5 \mu \mathrm{mol}$ reverse primer, $12.5 \mathrm{mM}$ dNTPs in a total reaction volume of $50 \mu \mathrm{L}$. Primers 16s rRNA-F: 5'-CGCCTGTTTAACAAAAACAT-3' and 16s rRNA-R: 5'-CCG

Genetics and Molecular Research 15 (3): gmr.15038503 
GTCTGAACTCAGATCATGT-3' and primers CR-F: 5'-AAGAACCAGCTAGGATAAAAC TTT-3' and CR-R: 5'-GATCAAAGAACATTCTTTAACTAC-3' were used to amplify 16s rRNA and CR genes, respectively. The amplification reaction was performed with an initial 2 min denaturation at $94^{\circ} \mathrm{C}$, followed by 35 cycles of $45 \mathrm{~s}$ at $94^{\circ} \mathrm{C}, 45 \mathrm{~s}$ at $50^{\circ} \mathrm{C}$, and $1 \mathrm{~min}$ at $72^{\circ} \mathrm{C}$, followed by a final extension for $10 \mathrm{~min}$ at $72^{\circ} \mathrm{C}$ for the $16 \mathrm{~s}$ rRNA gene. The amplification reaction was performed with an initial $3-\min$ denaturation at $94^{\circ} \mathrm{C}$, followed by 35 cycles of $15 \mathrm{~s}$ at $94^{\circ} \mathrm{C}, 20 \mathrm{~s}$ at $48.8^{\circ} \mathrm{C}$, and $40 \mathrm{~s}$ at $72^{\circ} \mathrm{C}$, followed by a 5 -min final extension at $72^{\circ} \mathrm{C}$ for the $\mathrm{CR}$ gene. PCR products were sent to Invitrogen Co. (Shanghai, China) for sequencing.

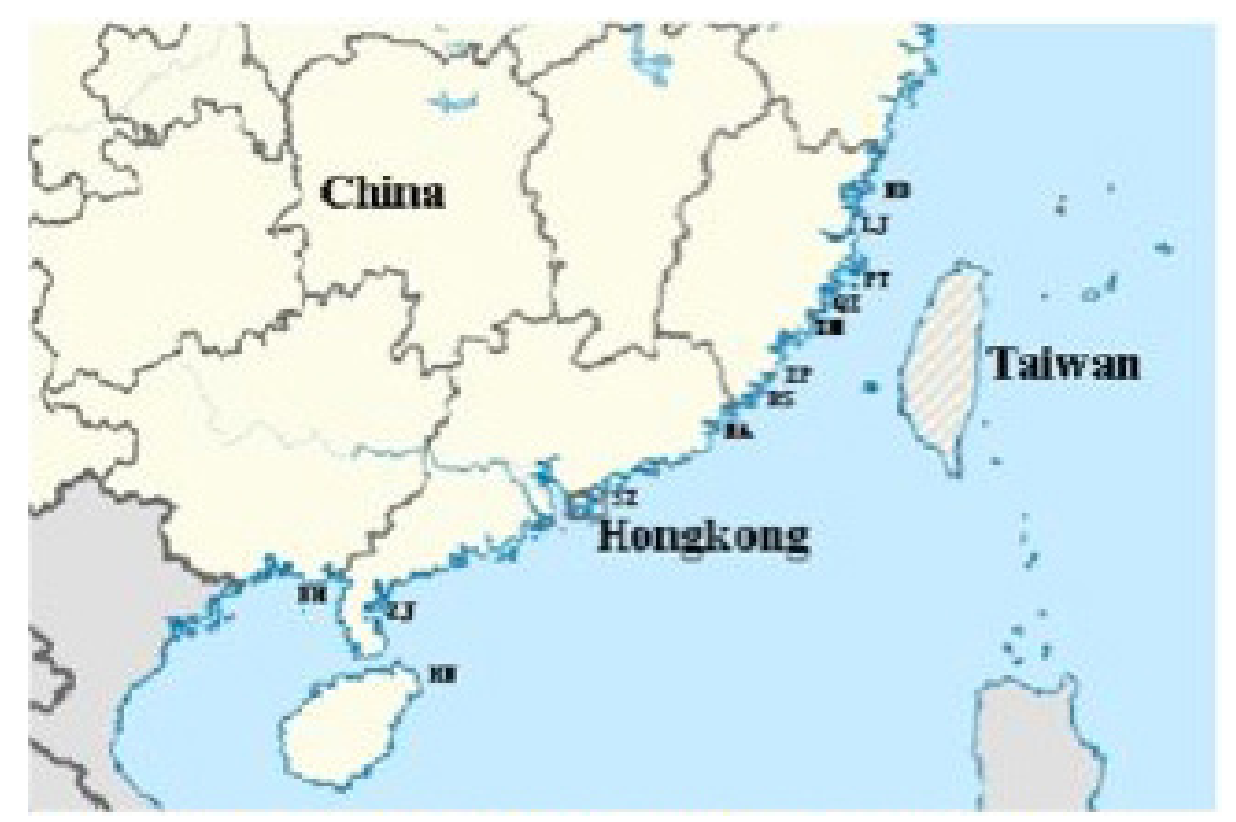

Figure 1. Sampling sites of 12 Fenneropenaeus penicillatus populations. ND: Ningde; LJ: Lianjiang; PT: Putian; QZ: Quanzhou; XM: Xiamen; ZP: Zhangpu; DS: Dongshan; NA: Nanao; SZ: Shenzhena; HN: Hainan; ZJ: Zhanjiang; BH: Beihai.

\section{Data analysis}

Sequences were edited and aligned using DNAMAN 6.0 (Lynnon Biosoft) and then manually adjusted to minimize mismatches. Nucleotide composition and variable sites were analyzed using BioEdit 7.0. Haplotype diversity $\left(H_{\mathrm{D}}\right)$, average number of nucleotide differences $(k)$, and mean sequence diversity $(\pi)$ were calculated using DnaSP 5.10 (Rozas et al., 2003). Arliquin 3.5 was used to analyze the number of mutations and genetic diversity (Excoffier and Lischer, 2010). Genetic distance among all individuals was calculated in MEGA 4.0 (Tamura et al., 2007). Hierarchical analysis of molecular variance (AMOVA) was performed to reveal the structure of genetic variation within and among populations. Network 4.6 (Rohl, 2003) was used to illustrate haplotype networks to determine phylogenetic relationships. 


\section{RESULTS}

\section{Genetic diversity}

PCR fragments 532 and 583 bp long were sequenced to identify 16s rRNA and CR gene segments, respectively. The average base composition of the 16s rRNA gene was: $\mathrm{T}=$ $33.6, \mathrm{C}=13.1, \mathrm{~A}=33.7, \mathrm{G}=19.6 \%$, and for the $\mathrm{CR}$ gene it was $\mathrm{T}=42.6, \mathrm{C}=11.2, \mathrm{~A}=39.1$, $\mathrm{G}=7.1 \%$. The GC content of the $16 \mathrm{~s}$ rRNA gene $(32.7 \%)$ was higher than that of the CR gene $(18.3 \%)$. The base composition was very similar among 12 populations for $16 \mathrm{~s}$ rRNA; however, the HN population was found to possess a slightly different base composition from the other 11 populations for the CR gene.

Among the $8516 \mathrm{~s}$ rRNA sequences, there were 16 mutation sites, making up 3.0\% of the total 532 sites analyzed. These 16 polymorphic sites included nine singleton variable sites and seven parsimony-informative sites. No insertions or deletions were observed in the examined sequences. Fourteen haplotypes were identified in the 85 samples. The number of haplotypes ranged from 1 to 5 for each population. The polymorphic sites ranged from 0 to 6 for each population. The average number of $k$ was lowest in the HN and ZP populations (0) and highest in the DS population (2.476). $H_{\mathrm{D}}$ and $\pi$ in 12 populations ranged from 0 to 0.810 and from 0 to 0.00466 , respectively (Table 2).

Table 2. Genetic diversity of the mtDNA 16s rRNA gene fragment in 12 Fenneropenaeus penicillatus populations.

\begin{tabular}{|c|c|c|c|c|c|c|}
\hline Population & Samples & Haplotypes & $H_{\mathrm{D}}$ & Polymorphic sites & $k$ & $\pi$ \\
\hline $\mathrm{BH}$ & 8 & 5 & 0.786 & 4 & 1.000 & 0.00188 \\
\hline$\underline{\mathrm{DS}}$ & 7 & $\underline{4}$ & $\underline{0.810}$ & $\underline{6}$ & 2.476 & 0.00466 \\
\hline$\overline{\mathrm{HN}}$ & $\frac{-}{6}$ & 1 & $\overline{0.000}$ & 0 & 0.000 & 0.00000 \\
\hline LJ & 7 & 2 & 0.286 & 1 & 0.286 & 0.00054 \\
\hline NA & 6 & 2 & 0.333 & 1 & 0.333 & 0.00063 \\
\hline ND & 9 & 2 & 0.222 & 1 & 0.222 & 0.00042 \\
\hline PT & $\underline{6}$ & 4 & 0.800 & $\underline{6}$ & 2.000 & 0.00376 \\
\hline$\overline{\overline{Q Z}}$ & $\overline{7}$ & 2 & $\overline{0.286}$ & $\overline{4}$ & $\overline{1.143}$ & $\overline{0.00215}$ \\
\hline$\underline{\mathrm{SZ}}$ & $\underline{7}$ & $\underline{3}$ & 0.667 & $\underline{5}$ & $\underline{1.619}$ & 0.00304 \\
\hline$\overline{\overline{X M}}$ & $\underline{6}$ & $\underline{2}$ & 0.533 & $\underline{4}$ & 2.133 & 0.00401 \\
\hline$\overline{\mathrm{ZJ}}$ & 8 & 3 & $\overline{0.464}$ & $\overline{2}$ & 0.500 & 0.00094 \\
\hline $\mathrm{ZP}$ & 8 & 1 & 0.000 & 0 & 0.000 & 0.00000 \\
\hline Total & 85 & 16 & 0.530 & 16 & 1.400 & 0.00264 \\
\hline
\end{tabular}

Underlined populations showed high genetic diversity and bold populations showed low genetic diversity. $H_{\mathrm{D}}$ : haplotype diversity; $k$ : nucleotide differences; $\pi$ : sequence diversity.

Among the $83 \mathrm{CR}$ sequences, there were 184 mutation sites, making up 31.5\% of the total 583 sites analyzed. These 184 polymorphic sites included 56 singleton variable sites and 128 parsimony-informative sites. No insertions or deletions were observed in the examined sequences. Seventy-nine haplotypes were identified in the 83 samples. The number of haplotypes ranged from 2 to 9 for each population. The polymorphic sites ranged from 10 to 113 for each population. The average number of $k$ was lowest in $\mathrm{HN}(8.036)$ and was highest in ZP population (54.900). $H_{\mathrm{D}}$ and $\pi$ in the 12 populations ranged from 0.964 to 1.000 and from 0.01378 to 0.09245 , respectively (Table 3 ).

Genetics and Molecular Research 15 (3): gmr.15038503 
Table 3. Genetic diversity of the mtDNA CR gene fragment in 12 Fenneropenaeus penicillatus populations.

\begin{tabular}{|c|c|c|c|c|c|c|}
\hline Population & Samples & Haplotypes & $H_{\mathrm{D}}$ & Polymorphic sites & $k$ & $\pi$ \\
\hline $\mathrm{BH}$ & 7 & 7 & 1.000 & 38 & 13.619 & 0.02344 \\
\hline$\underline{\mathrm{DS}}$ & $\underline{7}$ & $\underline{7}$ & $\underline{1.000}$ & $\underline{113}$ & $\underline{39.286}$ & $\underline{0.06762}$ \\
\hline$\overline{\mathrm{HN}}$ & 8 & 7 & $\overline{0.964}$ & $\overline{24}$ & 8.036 & $\overline{0.01378}$ \\
\hline LJ & 7 & 7 & 1.000 & 51 & 19.238 & 0.03311 \\
\hline NA & 9 & 9 & 1.000 & 48 & 16.250 & 0.02802 \\
\hline ND & 9 & 9 & 1.000 & 42 & 13.556 & 0.02329 \\
\hline$\underline{\mathrm{PT}}$ & $\underline{6}$ & $\underline{6}$ & $\underline{1.000}$ & $\underline{97}$ & $\underline{35.333}$ & $\underline{0.06071}$ \\
\hline$\underline{\mathrm{QZ}}$ & $\underline{8}$ & $\underline{8}$ & $\underline{1.000}$ & $\underline{113}$ & $\overline{53.714}$ & $\overline{0.09245}$ \\
\hline SZ & 2 & 2 & 1.000 & 10 & 10.000 & 0.01718 \\
\hline$\underline{\underline{\mathrm{XM}}}$ & $\underline{6}$ & $\underline{6}$ & $\underline{1.000}$ & $\underline{102}$ & $\underline{40.133}$ & $\underline{0.06908}$ \\
\hline$\overline{\mathrm{ZJ}}$ & $\overline{9}$ & $\overline{9}$ & $\overline{1.000}$ & $\overline{47}$ & $\overline{12.944}$ & $\overline{0.02228}$ \\
\hline$\underline{Z P}$ & $\underline{5}$ & $\underline{5}$ & $\underline{1.000}$ & $\underline{96}$ & $\underline{54.900}$ & $\underline{0.09433}$ \\
\hline Total & 83 & 79 & 0.999 & 184 & 36.065 & 0.06283 \\
\hline
\end{tabular}

Underlined populations showed high genetic diversity and bold populations showed low genetic diversity.

\section{Population structure}

Analysis of $16 \mathrm{~s}$ rRNA by AMOVA showed that $65.74 \%$ of the genetic variation occurred within populations, whereas $34.26 \%$ of the genetic variation occurred among populations. The average $F_{\mathrm{ST}}$ value was $0.34264(\mathrm{P}=0)$, suggesting significant genetic variation among these 12 populations. Pairwise genetic differentiation $\left(F_{\mathrm{ST}}\right)$ showed that genetic differentiation was low and statistically insignificant except for the comparison between $\mathrm{HN}$ and the other 11 populations $\left(F_{\mathrm{ST}}\right.$ ranged from 0.55368 to $\left.1.0000 ; \mathrm{P}<0.05\right)$ (Table 4$)$. High levels of genetic differentiation were found between $\mathrm{HN}$ and all other populations. The results also showed that the genetic distance ranged from 0 to 0.009 among the 12 wild $F$. penicillatus populations. A large genetic distance was also found between the HN population and the other 11 populations $(\mathrm{P} \geq 0.004)$ (Table 4).

Table 4. Genetic differentiation index from 16s rRNA (below diagonal) and CR regions (above diagonal).

\begin{tabular}{l|c|c|c|c|c|c|c|c|c|c|c|c}
\hline & BH & DS & HN & LJ & NA & ND & PT & QZ & SZ & XM & ZJ & ZP \\
\hline BH & - & 0.0200 & $\mathbf{0 . 8 6 5 6}^{*}$ & 0.0319 & 0 & 0.0095 & 0.0486 & 0.1900 & 0 & 0.0527 & 0 & $0.2837^{*}$ \\
\hline DS & 0.1027 & - & $\mathbf{0 . 6 7 2 9}^{*}$ & 0 & 0 & 0.0237 & 0 & 0 & 0 & 0 & 0.0279 & 0 \\
\hline HN & $\mathbf{0 . 8 7 2 1 *}^{*}$ & $\mathbf{0 . 5 5 3 7 ^ { * }}$ & - & $\mathbf{0 . 8 2 0 5}$ & $\mathbf{0 . 8 3 0 0 ^ { * }}$ & $\mathbf{0 . 8 5 4 4}$ & $\mathbf{0 . 6 9 9 2 *}$ & 0.4406 & 0.8989 & $\mathbf{0 . 6 6 4 0 *}$ & $\mathbf{0 . 8 5 1 2}$ & $\mathbf{0 . 4 6 0 5 *}$ \\
\hline LJ & 0 & 0.0894 & $\mathbf{0 . 9 6 2 5}^{*}$ & - & 0 & 0.0255 & 0 & 0.1274 & 0 & 0 & 0 & $0.1718^{*}$ \\
\hline NA & 0 & 0.0875 & $\mathbf{0 . 9 6 0 0}^{*}$ & 0.0020 & - & 0.0128 & 0.0475 & 0.1670 & 0 & 0.0166 & 0 & $0.2397^{*}$ \\
\hline ND & 0.0058 & 0.1379 & $\mathbf{0 . 9 3 5 8}^{*}$ & 0 & 0 & - & 0.0108 & $0.1947^{*}$ & 0 & 0.0488 & 0.0467 & $0.3053^{*}$ \\
\hline PT & 0.0157 & 0 & $\mathbf{0 . 7 2 7 3}^{*}$ & 0.0205 & 0 & 0.0427 & - & 0 & 0 & 0 & 0.0634 & 0.0195 \\
\hline QZ & 0.0013 & 0 & $\mathbf{0 . 8 2 0 3}^{*}$ & 0 & 0 & 0.0157 & 0 & - & 0 & 0 & $0.2095^{*}$ & 0 \\
\hline SZ & 0.0400 & 0 & $\mathbf{0 . 7 6 5 6}^{*}$ & 0.0476 & 0.0290 & 0.0666 & 0 & 0 & - & 0 & 0.0198 & 0.0597 \\
\hline XM & 0.1656 & 0 & $\mathbf{0 . 6 0 0 0}^{*}$ & 0.2052 & 0.1778 & 0.2248 & 0 & 0 & 0 & - & $0.0510^{*}$ & 0 \\
\hline ZJ & 0 & 0.1208 & $\mathbf{0 . 9 3 1 9}^{*}$ & 0 & 0 & 0.0009 & 0.0292 & 0.0077 & 0.0543 & 0.2045 & - & $0.2801^{*}$ \\
\hline ZP & 0 & $0.1455^{*}$ & $\mathbf{1}^{*}$ & 0.0204 & 0.0514 & 0.0141 & 0.0514 & 0.0204 & 0.07800 & 0.2615 & 0 & -
\end{tabular}

*Indicates $\mathrm{P}$ value lower than 0.05 . Numbers in bold represent signicantly high genetic differentiation between the two populations.

Analysis of CR by AMOVA showed that $69.70 \%$ of the genetic variation occurred within populations, whereas $30.30 \%$ of the genetic variation occurred among populations. The average $F_{\mathrm{ST}}$ value was $0.30296(\mathrm{P}=0)$, suggesting significant genetic variation among these 12 populations. Pairwise genetic differentiation $\left(F_{\mathrm{ST}}\right)$ revealed similar results as found for $16 \mathrm{~s}$

Genetics and Molecular Research 15 (3): gmr.15038503 
rRNA. The genetic differentiation was significant between HN populations and all other 11 populations except for the QZ and SZ populations (Table 5). In addition, the genetic distance was $0.019-0.171$ among 12 wild $F$. penicillatus populations. Large genetic distance was found between the HN population and the other 11 populations (0.107-0.171) (Table 5).

Table 5. Genetic distances between Fenneropenaeus penicillatus populations obtained from 16s rRNA (below diagonal) and CR regions (above diagonal).

\begin{tabular}{l|c|c|c|c|c|c|c|c|c|c|c|c}
\hline & BH & DS & HN & LJ & NA & ND & PT & QZ & SZ & XM & ZJ & ZP \\
\hline BH & - & 0.051 & $\mathbf{0 . 1 7 1}$ & 0.029 & 0.026 & 0.023 & 0.048 & 0.083 & 0.019 & 0.054 & 0.022 & 0.090 \\
\hline DS & 0.004 & - & $\mathbf{0 . 1 5 0}$ & 0.054 & 0.053 & 0.051 & 0.068 & 0.090 & 0.047 & 0.072 & 0.051 & 0.095 \\
\hline HN & $\mathbf{0 . 0 0 9}$ & $\mathbf{0 . 0 0 6}$ & - & $\mathbf{0 . 1 6 6}$ & $\mathbf{0 . 1 7 1}$ & $\mathbf{0 . 1 6 9}$ & $\mathbf{0 . 1 4 3}$ & $\mathbf{0 . 1 1 5}$ & $\mathbf{0 . 1 6 6}$ & $\mathbf{0 . 1 4 1}$ & $\mathbf{0 . 1 6 7}$ & $\mathbf{0 . 1 0 7}$ \\
\hline LJ & 0.001 & 0.003 & $\mathbf{0 . 0 0 8}$ & - & 0.031 & 0.030 & 0.053 & 0.085 & 0.026 & 0.056 & 0.028 & 0.087 \\
\hline NA & 0.001 & 0.003 & $\mathbf{0 . 0 0 8}$ & 0.001 & - & 0.028 & 0.053 & 0.085 & 0.024 & 0.056 & 0.027 & 0.089 \\
\hline ND & 0.001 & 0.003 & $\mathbf{0 . 0 0 8}$ & 0.000 & 0.001 & - & 0.048 & 0.083 & 0.019 & 0.053 & 0.025 & 0.090 \\
\hline PT & 0.003 & 0.004 & $\mathbf{0 . 0 0 7}$ & 0.002 & 0.002 & 0.002 & - & 0.088 & 0.044 & 0.068 & 0.049 & 0.093 \\
\hline QZ & 0.002 & 0.003 & $\mathbf{0 . 0 0 7}$ & 0.001 & 0.001 & 0.001 & 0.003 & - & 0.080 & 0.091 & 0.083 & 0.100 \\
\hline SZ & 0.003 & 0.004 & $\mathbf{0 . 0 0 7}$ & 0.002 & 0.002 & 0.002 & 0.003 & 0.002 & - & 0.050 & 0.020 & 0.085 \\
\hline XM & 0.003 & 0.004 & $\mathbf{0 . 0 0 5}$ & 0.003 & 0.003 & 0.003 & 0.004 & 0.003 & 0.003 & - & 0.053 & 0.092 \\
\hline ZJ & 0.001 & 0.003 & $\mathbf{0 . 0 0 8}$ & 0.001 & 0.001 & 0.001 & 0.002 & 0.002 & 0.002 & 0.003 & - & 0.087 \\
\hline ZP & 0.001 & 0.003 & $\mathbf{0 . 0 0 8}$ & 0.000 & 0.000 & 0.000 & 0.002 & 0.001 & 0.002 & 0.003 & 0.000 & - \\
\hline
\end{tabular}

Numbers in bold represent high genetic distance between the populations.

\section{Test of neutrality}

Based on the analysis of the 16s rRNA gene, Tajima's $D$ values in the BH and PT populations were found to be negative and significant. Furthermore, Fu's $F s$ values in the BH and ND populations were negative and significant (Table 6). Based on the analysis of the CR gene, Tajima's $D$ values and Fu's $F s$ values were all nonsignificant, and were mostly negative (Table 6).

Table 6. Tajima's $D$ test and Fu's $F$ s test based on $16 s$ rRNA and CR variation in 12 Fenneropenaeus penicillatus populations.

\begin{tabular}{l|c|c|c|c}
\hline & Tajima's $D(16 \mathrm{~s}$ rRNA) & $F s$ (16s rRNA) & Tajima's $D(\mathrm{CR})$ & $F s(\mathrm{CR})$ \\
\hline BH & $-1.53470^{*}$ & $-2.80014^{*}$ & -0.83039 & -0.89281 \\
\hline DS & 0.05645 & -0.87132 & -0.89194 & 0.50297 \\
\hline HN & 0.0000 & 0.00000 & -0.69292 & -0.88172 \\
\hline LJ & -1.00623 & -0.09474 & -0.34764 & -0.30459 \\
\hline NA & -0.93302 & -0.00275 & -0.39467 & -1.37963 \\
\hline ND & -1.08823 & $-1.08110^{*}$ & -0.56503 & -1.79628 \\
\hline PT & $-1.36732^{*}$ & -0.49899 & -0.97336 & 0.79524 \\
\hline QZ & -1.43414 & 2.04698 & 1.24808 & 0.46822 \\
\hline SZ & -1.02379 & 0.90397 & 0.00000 & 2.30259 \\
\hline XM & 1.18059 & 3.14583 & -0.55087 & 0.93247 \\
\hline ZJ & -1.31009 & -0.99899 & -1.10300 & -1.76553 \\
\hline ZP & 0.00000 & 0.00000 & 1.31412 & 1.68498 \\
\hline Mean & -0.70504 & -0.02094 & -0.31558 & -0.02784 \\
\hline Total & $-1.60501^{*}$ & $-9.11621^{*}$ & -0.01539 & $-24.13114 *$ \\
\hline
\end{tabular}

\section{Network analyses}

The network showed by the 16s rRNA gene was star-shaped and showed one central 
haplotype (H_1), which was the most common haplotype. Haplotype H_6 was from the HN population and was the most distant to the common haplotype (Figure 2).

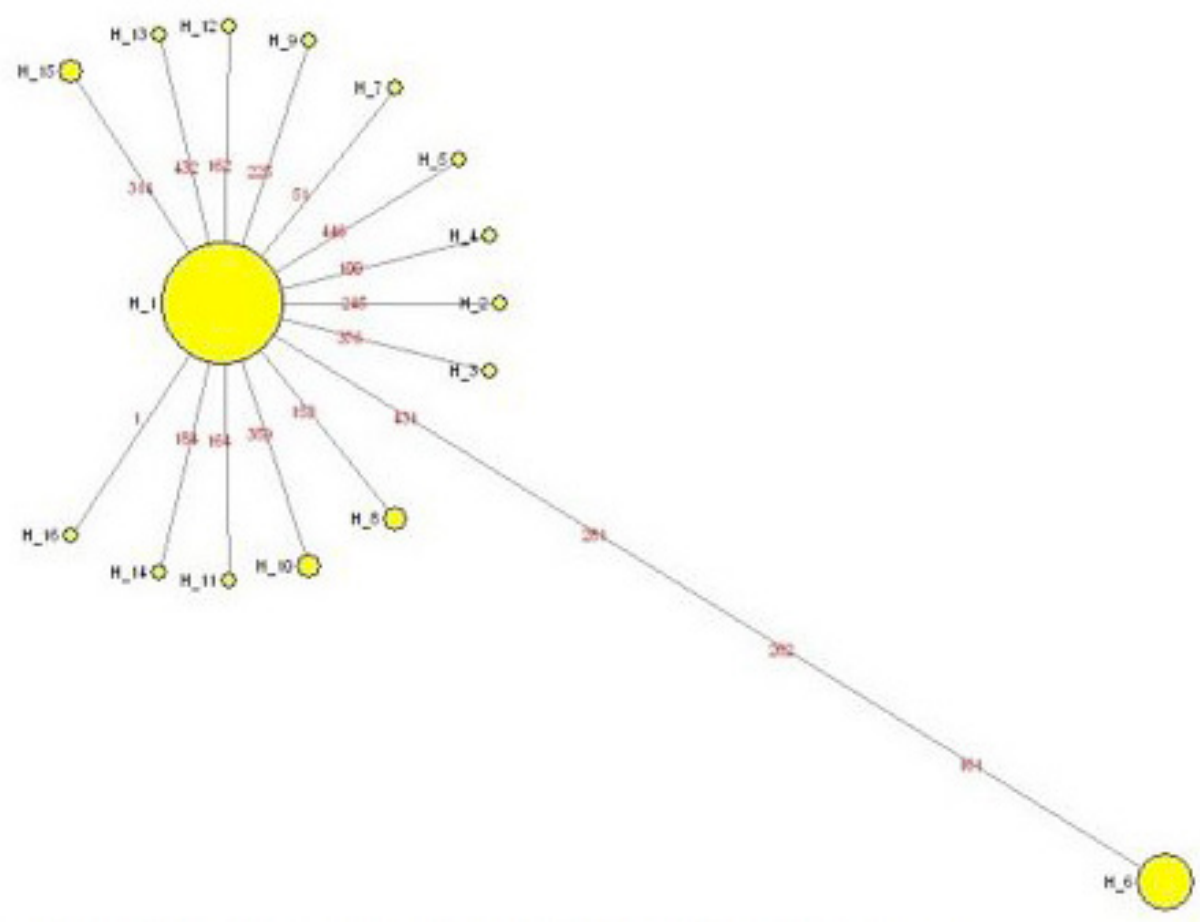

Figure 2. Network of phylogenetic relationships among 16 haplotypes in Fenneropenaeus penicillatus.

\section{DISCUSSION}

Analysis of the 16s rRNA gene showed that the HN and ZP populations have the lowest haplotype and nucleotide diversity $\left(H_{\mathrm{D}}=0 ; \pi=0\right)$. LJ, NA, and ND populations also have low haplotype and nucleotide diversity $\left(H_{\mathrm{D}}=0.5 ; \pi^{\%}<0.1\right)$ compared with the other populations. Analysis of the CR gene showed that all populations have high haplotype and nucleotide diversity. However, the HN population had the lowest nucleotide diversity among the 12 populations studied. Nucleotide diversity can be used to indicate the genetic diversity of a population (Nei and $\mathrm{Li}, 1979$ ). The difference in genetic diversity detected using 16s rRNA and $\mathrm{CR}$ was due to the CR gene having a much higher mutation rate than the 16s rRNA gene. Based on the results obtained by $16 \mathrm{~s}$ rRNA and CR analysis, the HN population was found to have the lowest genetic diversity, whereas BH, DS, XM, and PT populations have the highest genetic diversity. Genetic diversity provides insight into historical demography, population structure, and future conservation strategies, is influenced by many factors including historical factors, anthropogenic activity, and habitation (Avise, 2004; Grant et al., 2006), and is used to evaluate the ability of populations to cope with environmental changes. Therefore, attention should be given to populations with lower genetic diversity ( $\mathrm{NH}$ and $\mathrm{ZP}$ ), which

Genetics and Molecular Research 15 (3): gmr.15038503 
need special conservation management. The high genetic diversity found for the XM and PT populations was consistent with results showing the genetic diversity of $F$. penicillatus using the amplified fragment length polymorphism method (Zhang et al., 2012). Overall, the genetic diversity identified using the 16s rRNA gene was lower than that identified in the pink shrimp Farfantepenaeus duorarum, in which one fragment of mtDNA was used. However, genetic diversity within the $\mathrm{CR}$ was higher than that in the pink shrimp F. duorarum (McMillenJackson and Bert, 2004). This could be due to the different regions of mtDNA used.

The central-marginal hypothesis states that the genetic diversity of populations usually decreases from the center of a geographical range towards the periphery (Eckert et al., 2008). This could mean that XM and PT are at the center of the $F$. penicillatus populations, which are located along the southeast coast of China. However, only HN was on the edge of the geographical range of southeast $F$. penicillatus populations among those with the lowest genetic diversity (HN, ZP and SZ). ZP population is geographically in the middle of all sampled areas. Therefore, reasons other than the central-marginal hypothesis are important in shaping the population diversity along the southeast coast of China. The most likely factors are human activity, including overexploitation, marine pollution, and aquaculture. In addition, it is possible that the central-marginal hypothesis is better applied to terrestrial species than to marine species.

The results of Tajima's D test and Fu's $F$ s test for 16s rRNA suggested that the BH, PT, and ND populations may have experienced a recent population expansion. This is consistent with the star-shape haplotype network generated by the 16s rRNA gene, which is a typical signature of recent population expansion following a population bottleneck (Avise, 2004). Large population size due to population expansion may account for the high genetic diversity observed in the BH and PT populations. However, the genetic diversity of the ND population, which may have experienced a recent population expansion, was still low. This could be due to the fact that the size of the ND population is still recovering from a genetic bottleneck.

Based on the genetic structure results obtained from the 16s rRNA and CR analyses, the genetic differentiation among 12 wild $F$. penicillatus populations was found to be high. However, the high genetic differentiation is mainly caused by the high genetic differentiation between $\mathrm{HN}$ and the other 11 populations. The genetic differentiation among 11 populations (except the HN population) obtained by 16s RNA gene analyses was similar to that observed among five Litopenaeus vannamei brood stocks obtained by the COI gene fragment (Francisco and Galetti, 2005). The genetic differentiation obtained from 16s rRNA analysis between $\mathrm{HN}$ and the 11 other populations was slightly lower than that between $L$. vannamei and $F$. subtilis obtained from the COI gene fragment (Francisco and Galetti, 2005). The large genetic differentiation between the $\mathrm{HN}$ population and the other 11 populations was consistent with the geographic distribution of $\mathrm{HN}$, which is found on an island about $200 \mathrm{~km}$ away from mainland China. Although the distance between $\mathrm{HN}$ and mainland populations is not very far, the dispersal characteristics of $F$. penicillatus and the ocean currents may contribute to the isolation of the HN population. Adults spawn offshore, pelagic larvae migrate inshore, and juveniles spend months in mangroves and estuaries before migrating offshore (Dall et al., 1990). Restricted gene flow between $\mathrm{HN}$ and the other 11 populations may account for its very low genetic diversity. However, Hobbs et al. (2013) suggested that isolated marine species, unlike isolated terrestrial species, maintain a large population size in order to compensate for the effect of genetic drift and to maintain high genetic diversity. Thus, the small size of

Genetics and Molecular Research 15 (3): gmr.15038503 
the HN population is probably the key reason for its low genetic diversity. Low levels of genetic diversity may be accompanied by a higher risk of extinction for wild stocks and higher susceptibility to emerging pathogens for shrimp aquaculture (Cao et al., 2012). The main reasons for the small size of the HN population are probably overexploitation and habitat environmental changes.

In conclusion, the genetic structure results obtained in the present study were consistent using both 16s rRNA and CR genes in mtDNA. However, the genetic diversity results obtained were different. The CR gene revealed a high level of genetic diversity in all 12 wild $F$. penicillatus populations due to the high mutation rate of this gene. However, results for both 16s rRNA and CR showed that the HN population has very low genetic diversity compared to the other populations studied.

\section{Conflicts of interest}

The authors declare no conflict of interest.

\section{ACKNOWLEDGMENTS}

Research supported by the National Natural Science Foundation of China (\#31272668), the Foundation for Innovative Research Team of Jimei University, China (\#2010A004), the Natural Science Foundation of Fujian Province (\#2010J01213), the Program of Fujian Provincial Department of Science and Technology (\#JK2010034).

\section{RERERENCES}

Avise JC (2004). Molecular Markers, Natural History and Evolution, (second eds.). Sinauer, Sunderland, Massachusetts, 684.

Blier PU, Dufresne F and Burton RS (2001). Natural selection and the evolution of mtDNA-encoded peptides: evidence for intergenomic co-adaptation. Trends Genet. 17: 400-406. http://dx.doi.org/10.1016/S0168-9525(01)02338-1

Caetano-Anollés G (2002). Tracing the evolution of RNA structure in ribosomes. Nucleic Acids Res. 30: 2575-2587. http:// dx.doi.org/10.1093/nar/30.11.2575

Cao YY, Li ZB, Zhang GL, Chen XJ, et al. (2012). Isolation and characterization of ten microsatellite markers of Fenneropenaeus penicillatus. Conserv. Genet. Resour. 4: 261-263. http://dx.doi.org/10.1007/s12686-011-9520-6

Chai XJ (2001). Discuss on feed A in Penaeus penicillatus Alock breeding. J. Zhejiang Ocean Univ. (Natural Science) 20: 248-250. (in Chinese with English abstract).

Chen SL, Chen QX, Hu TH, Gong L, et al. (1997). Purification and properties of acid phosphatase from Penaeuspenicillatus (Alcock). J. of Xiamen University (Natrual Science), 36: 121-125. (in Chinese with English abstract).

Croos de MDST and Pálsson S (2010). Mitochondrial DNA variation and population genetic structure of white-shrimp Fenneropenaeus indicus along the coastal belt of Sri Lanka. Aquat. Living. Resour. 23: 315-323. http://dx.doi. org/10.1051/alr/2010027

Dall W, Hill BJ, Rothlisberg PC and Staples DJ (1990). The Biology of the Penaeidae (Blaxter JHS and Southward AJ, eds.). Adv. Mar. Biol. 27: 1-489.

Duda TF and Palumbi SR (1999). Population structure of the black tiger prawn, Penaeus monodon, among western India Ocean and western Pacific populations. Mar. Biol. 134: 705-710. http://dx.doi.org/10.1007/s002270050586

Dyall SD, Brown MT and Johnson PJ (2004). Ancient invasions: from endosymbionts to organelles. Science 304: 253257. http://dx.doi.org/10.1126/science.1094884

Eckert CG, Samis KE and Lougheed SC (2008). Genetic variation across species' geographical ranges: the centralmarginal hypothesis and beyond. Mol. Ecol. 17: 1170-1188. http://dx.doi.org/10.1111/j.1365-294X.2007.03659.x

Englbrecht CC, Freyhof J, Nolte A, Rassmann K (2000). Phylogeography of the bullhead Cottus gobio (Pisces: Teleostei: Cottidae) suggests a pre-Pleistocene origin of the major central European populations. Mol. Ecol. 9: 709-722. http://

Genetics and Molecular Research 15 (3): gmr.15038503 
dx.doi.org/10.1046/j.1365-294x.2000.00912.x

Excoffier L and Lischer HEL (2010). Arlequin suite ver 3.5: A new series of programs to perform population genetics analyses under Linux and Windows. Mol. Ecol. Resour. 10: 564-567. http://dx.doi.org/10.1111/j.17550998.2010.02847.x

Francalacci P, Bertranpetit J, Calafell F, Underhill PA (1996). Sequence diversity of the control region of mitochondrial DNA in Tuscany and its implications for the peopling of Europe. Am. J. Phys. Anthropol. 100: 443-460. http://dx.doi. org/10.1002/(SICI)1096-8644(199608)100:4<443::AID-AJPA1>3.0.CO;2-S

Francisco AK and Galetti PM (2005). Genetic distance between broodstocks of the marine shrimp Litopenaeus vannamei (Decapoda, Penaeidae) by mtDNA analyses. Genet. Mol. Biol. 28: 258-261. http://dx.doi.org/10.1590/S1415$\underline{47572005000200014}$

Grant WS, Spies IB and Canino MF (2006). Biogeographic evidence for selection on mitochondrial DNA in North Pacific Walleye Pollock Theragra chalcogramma, J. Hered. 97: 571-580. http://dx.doi.org/10.1093/jhered/es1033

Gruenthal KM, Acheson LK and Burton RS (2007). Genetic structure of natural populations of California red abalone (Haliotis rufescens) using multiple genetic markers. Mar. Biol. 152: 1237-1248. http://dx.doi.org/10.1007/s00227$\underline{007-0771-4}$

Hobbs JA, Herwerden L, Jerry DR, Jones GP et al. (2013). High genetic diversity in geographically remote populations of endemic and widespread coral reef angelfishes (genus: Centrophyge). Diversity. 5: 39-50. http://dx.doi.org/10.3390/ $\underline{\mathrm{d} 5010039}$

Kamal T, Tanoli MAK, Mumtaz M, Ali N, et al. (2015). Bioconcentration potential studies of heavy metals in Fenneropenaeus penicillatus (Jaira or red tail shrimp) along the littoral states of Karachi city. J. Basic Applied Sci. 11: 611-618. http://dx.doi.org/10.6000/1927-5129.2015.11.82

Li JB, Wang XZ, Kong XH, Zhao K, et al. (2008). Variation patterns of the mitochondrial 16S rRNA gene with secondary structure constraints and their application to phylogeny of cyprinine fishes (Teleostei: Cypriniformes). Mol. Phylogenet. Evol. 47: 472-487. http://dx.doi.org/10.1016/j.ympev.2007.09.012

McMillen-Jackson AL and Bert TM (2004). Genetic diversity in the mtDNA control region and population structure in the pink shrimp Farfantepenaeus duorarum, J. Crustac. Biol. 24: 101-109. http://dx.doi.org/10.1651/C-2372

McNeely JA, Miller KR, Reid WV, Mittermeier RA, et al. (1990). Conserving the World's Biological Diversity. IUCN, World Resources Institute, Conservation International, WWF-US and the World Bank: Washington, DC.

Nei M and Li WH (1979). Mathematical model for studying genetic variation in terms of restriction endonucleases. Proc. Natl. Acad. Sci. U. S. A. 76: 5269-5273. http://dx.doi.org/10.1073/pnas.76.10.5269

Park LK and Moran P (1994). Development in molecular genetics techniques in fisheries. Rev. Fish. Biol. Fish. 4: 272-299. http://dx.doi.org/10.1007/BF00042906

Quan JX, Zhuang ZM, Deng JY, Dai JX, et al. (2004). Phylogenetic relationships of 12 penaeoidea shrimp species deduced from mitochondrial DNA sequences. Biochem. Genet. 42: 331-345. http://dx.doi.org/10.1023/ B:BIGI.0000039808.12069.ed

Rohl A (2003). Network: A program package for calculating phylogenetic networks, version 4.6 Fluxus Technology Ltd., Hamburg (Germany).

Rozas J, Sanchez-DelBarrio JC, Messeguer X and Rozas R (2003). DnaSP, DNA polymorphism analyses by coalescent and other methods. Bioinformatics 19: 2496-2497. http://dx.doi.org/10.1093/bioinformatics/btg359

Shangguan JB, Li ZB, Li QH, Dai G, et al. (2014). Screening and characterization of new microsatellite markers in Fenneropenaeus penicillatus. Genet. Mol. Res. 13: 6079-6082. http://dx.doi.org/10.4238/2014.August.7.22

Sloan DB, Barr CM, Olson MS, Keller SV, et al. (2008). Evolutionary rate variation at multiple levels of biological organization in plant mitochondrial DNA. Mol. Biol. Evol. 25: 243-246. http://dx.doi.org/10.1093/molbev/msm266

Tamura K, Dudley J, Nei M and Kumar S (2007). MEGA4: Molecular Evolutionary Genetics Analysis (MEGA) software version 4.0. Mol. Biol. Evol. 24: 1596-1599. http://dx.doi.org/10.1093/molbev/msm092

Thorrold SR, Jones GF, Hellberg ME, Burton RS, et al. (2002). Quantifying larval retention and connectivity in marine populations with artificial and natural markers. Bull. Mar. Sci. 70: 291-308.

Whitehead A, Anderson SL, Kuivila KM, Roach JL et al. (2003) Genetic variation among interconnected populations of Catostomus occidentalis: implications for distinguishing impacts of contaminants from biogeographical structuring. Mol. Ecol. 12: 2817-2833. http://dx.doi.org/10.1046/j.1365-294X.2003.01933.x

Yuan Y, Li ZB, Ning YF, Deng HW, et al. (2015). Development and characterization of new microsatellite markers of Fenneropenaeus penicillatus. Genet. Mol. Res. 14: 6679-6682. http://dx.doi.org/10.4238/2015.June.18.11

Zhang GL, Cao YY, Li ZB, Chen J, et al. (2012). Analysis of the genetic diversity and differentiation of Fenneropenaeus penicillatus populations using AFLP technology. Chin. J. Oceanol. Limnol. 30: 440-445. http://dx.doi.org/10.1007/ $\underline{\mathrm{s} 00343-012-1125-8}$

Genetics and Molecular Research 15 (3): gmr.15038503 